\title{
The Effect Of Cricket Flour Addition (Acheta Domesticus) In Feed On Production Performance Of Quail (Cortunix Cortunix Japonica)
}

\author{
Bagus Andika Fitroh ${ }^{1}$, Adib Norma Respati ${ }^{1}$, dan Putri Awaliya Dughita ${ }^{1}$ \\ ${ }^{1}$ Animal Husbandry Program, Faculty of Engineering, Science, and Agriculture \\ J1. Agus Salim No. 10 Surakarta 57147 \\ Email : andikafitroh78@gmail.com
}

\begin{abstract}
The purpose of this research was to study the effect of cricket flour addition on production performance of quail including: feed consumption, egg production, and feed convertion. There were 240 female of quail selected at 47 days of age which were divided into four treatments including: $100 \%$ of basal feed (P0), 95\% of basal feed + $5 \%$ of cricket flour (P1), $90 \%$ of basal feed $+10 \%$ of cricket flour (P2), $85 \%$ of basal feed $+15 \%$ of cricket flour $(\mathrm{P} 3)$. The research method used was experiment using completely random design. The obtained data were analyzed by Anova (Analysis of variance), if there was significant different it would be tested by Duncan's Multipel range test (DMRT). The results of this research showed that the addition of cricket flour on feed give a significantly different on $(\mathrm{P}<0.01)$ feed consumption, egg production, and feed conversion. The highest to the lowest of feed consumption was T3 (23.83 \pm $\left.0.09^{\mathrm{d}}\right), \mathrm{T} 2\left(23.62 \pm 0.05^{\mathrm{c}}\right), \mathrm{T} 1\left(23.41 \pm 0.11^{\mathrm{b}}\right)$, T0 $\left(23.21 \pm 0.08^{\mathrm{a}}\right)$; the highest to the lowest of HDP was T3 $\left(91.01 \pm 2.09^{\mathrm{c}}\right), \mathrm{T} 2\left(87.68 \pm 3.06^{\mathrm{b}}\right), \mathrm{T} 1\left(86.13 \pm 5.51^{\mathrm{b}}\right)$, T0 $\left(79.71 \pm 4.58^{\mathrm{a}}\right)$; the highest to the lowest of egg mass was T3 $\left(8.65 \pm 0.20^{\mathrm{b}}\right)$, T2(8.33 \pm $\left.0.29^{\mathrm{b}}\right), \mathrm{T} 1\left(8.19 \pm 0.52^{\mathrm{b}}\right), \mathrm{T} 0\left(7.57 \pm 0.44^{\mathrm{a}}\right)$; the highest to the lowest of feed conversion was T0 $\left(3.09 \pm 0.19^{\mathrm{c}}\right), \mathrm{T} 1\left(2.89 \pm 0.19^{\mathrm{b}}\right)$, T2 $\left(2.85 \pm 0.10^{\mathrm{ab}}\right)$, T3 $\left(2.76 \pm 0.06^{\mathrm{a}}\right)$. The conclusions of this research was that the addition of cricket flour in feed can improve performance production of quail. The best treatment was T3 with the addition of $15 \%$ cricket flour in feed it is advisable toget the best results should be used cricket flour respectively $15 \%$ in feed and used basal feed in mash to feed can be mixed perfectly with cricket flour.
\end{abstract}

Keywords : cricket flour, quail, quail performance.

\section{Introduction}

Quail is a type of poultry that can produce eggs and meat and plays an important role in improving community nutrition, especially as a source of animal protein. Quail care that must always be considered is the need for feed with complete nutrition, drinking water, good air ventilation, temperature and humidity, and the health of the quail itself. The most important factor in the success of raising quail is the feed factor (nutrition). Feed is considered the most important factor, because $80 \%$ of production costs are contributed by feed (Saleh, 2005). Feed management covers the way of giving and nutritional needs according to age range. Nutrients that must be considered include: protein, carbohydrates, fats, vitamins, minerals and water absolutely must be available in sufficient quantities. 
Cricket is one type of insect that can be found easily in Indonesia, crickets are currently being developed because of its easy maintenance, besides, crickets are in great demand because they are used as food for animals such as birds chirping and pet fish.

Crickets are used as an alternative feed because crickets are believed to contain good nutrition, the contents of the cricket's body include protein about $60 \%$, fat around $8.20 \%$, dry matter around $22.52 \%$ and energy around $6172.88 \mathrm{kcal} / \mathrm{kg}$ with a moisture content of around $6.0 \%$ (Farida, 2008).

Quails are able to produce high egg production, and to support egg production, it requires sufficient sources of nutrients, so it is necessary to conduct experiments in adding crickets in quail feed.

At present the process of processing crickets into flour has been done a lot, cricket flour has become one of the mixed feed ingredients used as poultry or fish feed because cricket flour is more efficient when mixed with other feed ingredients if it has to provide living conditions to livestock.

\section{Location of the study}

\section{Research Materials And Methods}

The research was conducted at quail farm Mr. Samsudin Ampeldento, Karangploso, Malang on February 02 to March 1, 2015. Approximate analysis of basal feed was carried out at the Nutrition and Animal Feed Laboratory, Animal Husbandry Faculty, Brawijaya University, Malang.

\section{Research Material}

Quail used in this research were Female Coturnix Coturnix Japonica, 47 days old of layer, about 240 quails. The shape of the enclosure used is a battery which is blocked by 24 parts. Each bulkhead is filled with 10 quails. Cricket flour was obtained from the Malang City Splindid market and the basal feed used was commercial finished feed.

Table 1. Results of Proximate Analysis of Cricket flour

\begin{tabular}{lc}
\hline \multicolumn{1}{c}{ Food matter } & Nutritional Content \\
\hline Dry matter $(\% \mathrm{BK})$ & 22.52 \\
Energy (kkal/kg) & 6172.88 \\
Crude Protein $(\% \mathrm{BK})$ & 60.47 \\
Crude Fat $(\% \mathrm{BK})$ & 8.20 \\
Beta-N $(\% \mathrm{BK})$ & 19,57 \\
Crude Fiber $(\% \mathrm{BK})$ & 7.30 \\
Ash $(\% \mathrm{BK})$ & 4.46 \\
Calcium $(\% \mathrm{BK})$ & 0.71 \\
Phosphorus $(\% \mathrm{BK})$ & 0.07
\end{tabular}

Source: Farida (2008) 
Table 2. Nutritional Content of each Nutrition Treatment (Based on Manual Calculation)

\begin{tabular}{lccccc} 
Treatment & $\begin{array}{c}\text { PK } \\
(\%)\end{array}$ & $\begin{array}{c}\text { LK } \\
(\%)\end{array}$ & $\begin{array}{c}\text { SK } \\
(\%)\end{array}$ & $\begin{array}{c}\text { ABU } \\
(\%)\end{array}$ & $\begin{array}{c}\text { EM } \\
(\mathrm{kkal} / \mathrm{kg})\end{array}$ \\
\hline T0 & 20.00 & 3.50 & 5.00 & 12.00 & 2842.18 \\
T1 & 22.97 & 3.74 & 5.12 & 11.62 & 3008.67 \\
T2 & 24.50 & 4.40 & 5.29 & 11.25 & 3175.16 \\
T3 & 26.24 & 4.84 & 5.44 & 10.87 & 3341.65
\end{tabular}

\section{Research methods}

The research method used was an experiment using a completely randomized design pattern (CRD). The treatment given was the addition of cricket flour to basal feed by $5 \%, 10 \%$, and $15 \%$, with one treatment without the addition of cricket flour. The frequency of feeding as much as 1 time a day by giving $25 \mathrm{~g} / \mathrm{head} /$ day and drinking water is given as an add libitum for 28 days.

Masing-masing perlakuan yang diberikan adalah sebagai berikut :

T0: $100 \%$ basal feed without cricket flour addition

T1: $95 \%$ basalt feed $+5 \%$ cricket flour

T2: $90 \%$ basalt feed $+10 \%$ cricket flour

T3: $85 \%$ basalt feed $+15 \%$ cricket flour

\section{Research variables}

- Feed consumption

- HDP (Hen Day Production)

- Mass Egg Mass

- FCR (feed convertion ratio)

Results and Discussion

Table 4. Data of Average Feed Consumption, HDP, Egg mass, and Feed Conversion During Research (28 days)

\begin{tabular}{ccccc}
\hline & \multicolumn{3}{c}{ Study Variables } \\
\hline Treatments & Feed consumption & HDP & Egg mass & $\begin{array}{c}\text { Feed } \\
\text { Conversion }\end{array}$ \\
\hline & (g/chick/day) & $(\%)$ & $(\mathrm{g})$ & \\
\hline T0 & $23.21 \pm 0.08^{\mathrm{a}}$ & $79.71 \pm 4.58^{\mathrm{a}}$ & $7.57 \pm 0.44^{\mathrm{a}}$ & $3.09 \pm 0.19^{\mathrm{c}}$ \\
T1 & $23.41 \pm 0.11^{\mathrm{b}}$ & $86.13 \pm 5.51^{\mathrm{b}}$ & $8.19 \pm 0.52^{\mathrm{b}}$ & $2.89 \pm 0.19^{\mathrm{b}}$ \\
T2 & $23.62 \pm 0.05^{\mathrm{c}}$ & $87.68 \pm 3.06^{\mathrm{b}}$ & $8.33 \pm 0.29^{\mathrm{b}}$ & $2.85 \pm 0.10^{\mathrm{ab}}$ \\
T3 & $23.83 \pm 0.09^{\mathrm{d}}$ & $91.01 \pm 2.06^{\mathrm{c}}$ & $8.65 \pm 0.20^{\mathrm{b}}$ & $2.76 \pm 0.06^{\mathrm{a}}$ \\
\hline
\end{tabular}

Note : Note: Different superscripts $(a, b, c, d)$ in the same column show very significant differences $(\mathrm{P}<0.01)$. 


\section{Effect of Adding Cricket Flour to Feed Consumption}

Based on observations on feed consumption, it turns out that after analysis of variance shows that the addition of cricket flour in feed has a very significant effect ( $P$ $<0.01)$ on feed consumption. The average results of various treatments, showed that the highest feed consumption was found in the P3 treatment of $23.83 \pm 0.09$ (g/ head / day). The increase in feed consumption in various treatments can be presented in Figure 1.

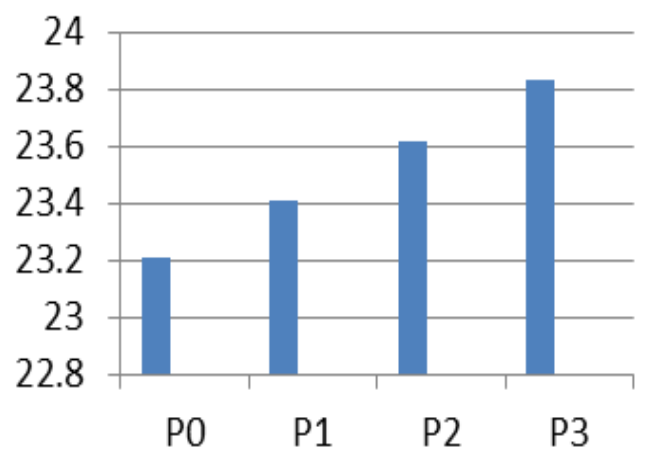

Figure 1. Feed Consumption Increase (g/quail/day) during research

The addition of cricket flour in the feed can cause an increase in consumption of laying quail, this is because the consumption of feed is strongly affected by the composition in the feed such as the amount of protein, energy content, and the content of some amino acids. Increased feed consumption can also be caused by the amino acid content contained in the feed, such as lisyne, arginine, cystine, tryptophan (Prayogi, 2011).

Quails have a limited sensing system, so they will prefer feed that has more striking color and soft texture. Quails prefer feed in a softer form accompanied by a lighter color compared to feed in the form of crumble or pellet (Rajput et al., 2016). Ocak and Erener (2005) Quail layer prefers the mashed feed form, because it is easier to take by the beak and makes it easier to swallow.

Changes in crude protein content in feed can affect production performance and will ultimately affect energy needs, so that if there is a change in feed consumption is caused indirectly by changes in feed protein content. Widyatmoko (2013) changes in nutrient content in poultry feed can cause an increase or decrease in the amount of feed consumption, in line with the desired goals in making rations.

\section{Effect of Cricket flour Addition on Hen Day Production}

Based on the results of observations on HDP, it turns out that after analysis of variance showed that the addition of cricket flour in feed gave a very significant effect $(\mathrm{P}<0.01)$ on HDP. The average results of various treatments, showed that the highest HDP value was found in the P3 treatment of $91.01 \pm 2.06 \%$. The increase in HDP values in various treatments is presented in Figure 2. 


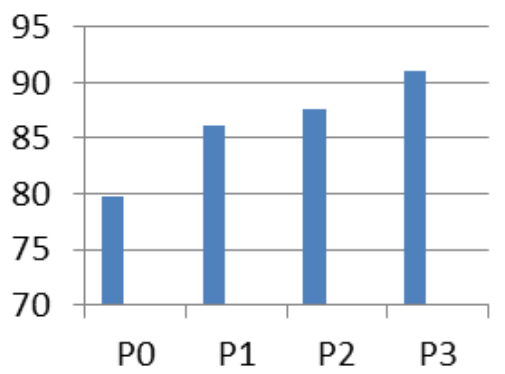

Figure 2. HDP\% increase per unit Treatment During Research (28 days).

The addition of cricket flour in feed can cause an increase in HDP value, this is due to differences in the amount of different protein consumption in the feed, the higher the percentage of cricket flour addition, the higher protein in feed that is followed by an increase in HDP. The highest protein content in the research feed variation is $22 \%$, giving higher egg yield compared to the treatment of feeding with a protein content of 20-19\%, this of course also affects the HDP increase in laying quails (Adebisi et al., 2016). Quail layer layer requires about $22 \%$ protein for production needs.

The amount of feed consumed has an effect on egg production, where the lower energy content and protein in high feed can increase the amount of egg production in quails. (Khosro et al., 2011) egg production results are more increased, because quails consume feed with a lower energy content of around $2900 \mathrm{kcal} / \mathrm{kg}$ EM, but have a high protein of around $20 \%$. Garcia et al (2005) higher egg production results are influenced by the amount of energy in the feed of 2900kcal / $\mathrm{kg}$ EM and protein around 22\%, the portion shows the adequacy rate for quail laying phase.

\section{Effect of Adding Cricket Flour on Egg Mass}

Based on the results of observations of egg mass, it turns out that after analysis of variance shows that the addition of cricket flour in feed gives a very significant effect ( $P$ $<0.01)$ on egg mass. The average results of various treatments, showed that the highest egg mass was found in the P3 treatment of $8.65 \pm 0.20 \mathrm{~g}$. The increase in egg mass in various treatments is presented in Figure 3.

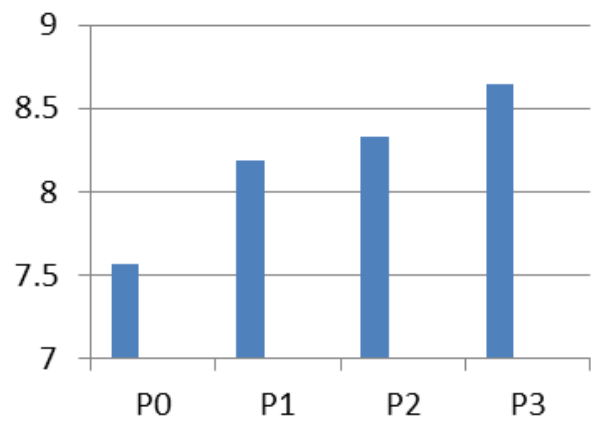

Figure 3. Egg mass increase per unit during the study (28 days). 
The figure above shows that the effect of adding cricket flour in feed can cause an increase in egg mass, this is due to the addition of cricket flour in feed, so as to increase egg production followed by an increase in egg mass.

Cricket flour has a fairly good nutritional value for quail, with $60 \%$ protein cricket flour can complement the needs of protein used by quail to increase egg production. Protein is very useful to support the activity of egg production for quail, so that with the presence of sufficient protein in each feed treatment egg production is increasing which is followed by an increase in egg mass. According Cath et all (2012), the higher level of egg production and egg weight, the higher the egg mass, and vice versa, the lower the egg production, the egg mass will also decrease. Feed consumed affects livestock production, where low feed consumption will produce low egg production, and high feed consumption will produce high production too.

The addition of cricket flour in different feeds caused different egg mass produced. It can be said that increasing the percentage of cricket flour in feed can increase the quail egg mass. The main factor affecting production is the feed factor because feed will determine the good and bad of livestock in producing eggs if the feed does not meet the nutritional needs in accordance with the needs of livestock (Jahanian and Edris, 2015).

\section{Effect of Adding Cricket Flour to Feed Conversion}

Based on observations on feed conversion, it turns out that after analysis of variance shows that the addition of cricket flour in feed has a very significant effect ( $P$ $<0.01)$ on feed conversion. The average results of various treatments showed the highest feed conversion at P0 treatment was $3.09 \pm 0.19$. The reduction in feed conversion in various treatments is presented in Figure 4.

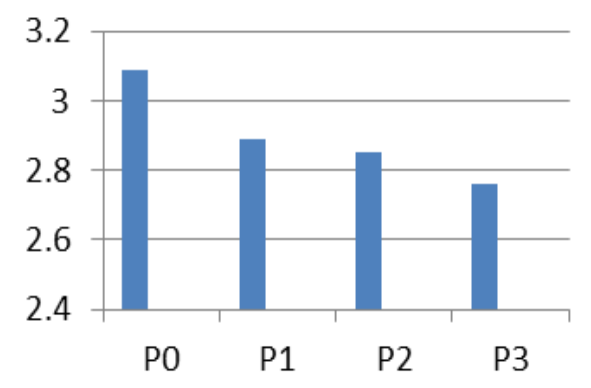

Figure 4. Decrease in Feed Conversion Per Unit During Research (28 days).

The figure above shows that the addition of cricket flour in feed can cause a decrease in feed conversion, this is due to the higher percentage of cricket flour addition in feed, resulting in higher egg production, although there is an increase in feed consumption but feed conversion decreases due to the number of eggs the resulting increase with increasing percentage of cricket flour in feed. The smaller the value of feed conversion, the better because it shows that the use of feed is more efficient (Siyadati et al., 2011).

Feed conversion is greatly affected by the consumption of feed and egg production produced, the high protein content in cricket flour can reduce feed 
conversion because by increasing the protein in each treatment feed, the number of eggs produced is also increasing, besides the decrease in conversion is also affected by the environment, feed form, scattered feed, and genetics. Reda et al (2015) explain that the factors that influence feed conversion are the physical form of feed, body weight, food content in feed, ambient temperature and gender Differences in feed conversion due to differences in feed consumption and egg production (Monica et al., 2010).

\section{Conclusion}

The percentage of cricket flour addition up to $15 \%$ gives the best results in terms of HDP, egg mass, and feed conversion. But there is an increase in feed consumption.

\section{References}

Adebisi, F. A., B. R. O. Omidiwura, D. Y. Ologbosere, and E. A. Iyayi. 2006. Determination of crude protein and metabolisable energy of japanese quail (Coturnix coturnix japonica) during laying period. J. World Poult. Res. 6(3): 131138.

Cath, A. U., M. Bozkurt, K. Kucukyilmaz, M. Cinar, E. Bintas, F. Coven, and H. Atik. 2012. Performance and egg quality or aged laying hens feed diets supplemented with meat and bone flour or oyster shell flour. South African Journal of Animal Science. 42(1): 21-18.

Garcia, E. A., A. A. Mendes, C. C. Pizzolante, J. Moreira, C. Mori, and A. C. Pavan. 2005. Protein, methionine plus cystine and lysine levels for Japanese quails during the production phase. Brazilian Journal of Poultry Science. 7(1): 11-18.

Jahanian, R. and M. A. Edriss. 2015. Metabolizable energy and crude protein requirements of two Quail species (Coturnix japonica and Coturnix ypsilophorus). The Journal of Animal and Plant Sciences. 25(3): 603-611.

Khosro, G., I. Mehrelad, J. Reza, M. A. Afshar, A. S. Seyed, and J. V. Abbas. 2011. The effect of energyto protein ratio on production performance and characteristics of Japanese quail eggs. Annals of Biological Reseach. 2(2): 122-128.

Monica, P., C. A. Ioana, S. Violeta-Elena, B. Carmen, and A. Adriana. 2010. Feed conversion efficiency in Japanese quail egg production. Mathematical Assisted University Spiru.

Ocak, N. and G. Erener. 2005. The effects of restricted feeding and feed form on growth, carcass characteristics and days to first egg of Japanese quail (Coturnix coturnix japonica). Australasian Journal of Animal Sciences. 18(10): 1479-1484.

Prayogi, H.S. 2011. The effect of earthworm flour supplementation in the diet on quail's growth performance in attempt to replace the usage of fish flour. International Journal of Poultry Science. 10(10): 804-806.

Rajput, N., M. Naeem, S. Ali, A. M. Shah, H. Rizwana, A. R. Shah, and A. R. Jehejo. 2016. Effect of various forms of feed on growth performance of Japanese quail. Res. Jour. (Sci. Ser.) 48(4): 879-882. 
Reda, F. M., E. A. Ashour, M. Alagawany, and M. E. Abd El-Hack. 2015. Effects of dietary protein, energy and lysine intake on growth performance and carcass characteristics of growing Japanese quails. Asian Journal of Poultry Science. 9: 155-164.

Siyadati, S. A., A. Mirzaei-Aghsaghali, and H. Ghazvinian. 2011. Effect of varying ratio of energy and protein on live performance and visceral organs of male Japanese quail. Annals of Biological research. 2(2):137-144.

Widyatmoko. H. 2013. Pengaruh penggunaan corn dried distillers grains with solubles dalam ransum terhadap performa puyuh jantan. J. buletin peternakan. 37(2): 120124. 